Jurnal Agro 8(2), 2021

\title{
INDUKSI KALUS DAUN BINAHONG MERAH (Basella rubra L.) DENGAN PEMBERIAN 2,4-D DAN KINETIN
}

\section{CALLUS INDUCTION OF RED BINAHONG (Basella rubra L.) LEAF WITH ADDITION OF 2,4-D AND KINETIN}

\author{
Fetmi Silvina*, Isnaini, Widya Ningsih \\ Jurusan Agroteknologi, Fakultas Pertanian, Universitas Riau \\ Simpang Baru, Kec. Tampan, Kota Pekanbaru, Riau 28292 \\ *Korespondensi: fetmi.silvina@lecturer.unri.ac.id
}

Diterima : 27 September 2021 / Disetujui : 16 Desember 2021

\begin{abstract}
ABSTRAK
Tanaman binahong merah (Basella rubra L.) merupakan salah satu tanaman yang mengandung senyawa metabolit sekunder berkhasiat obat. Kultur kalus adalah salah satu solusi dalam menghasilkan senyawa metabolit sekunder dengan jumlah yang besar. Penelitian ini bertujuan untuk mengetahui pengaruh pemberian 2,4-D dan kinetin dalam menginduksi kalus daun binahong merah. Penelitian dilakukan di Laboratorium Bioteknologi Tanaman Fakultas Pertanian Universitas Riau pada bulan November 2019 sampai Maret 2020. Percobaan menggunakan rancangan acak kelompok yang terdiri dari dua faktor yaitu 2,4-D dengan empat taraf konsentrasi yaitu $0 \mathrm{ppm}, 0,5 \mathrm{ppm}, 1 \mathrm{ppm}$ dan $2 \mathrm{ppm}$ dan kinetin dengan empat taraf konsentrasi yaitu $0 \mathrm{ppm}, 0,5 \mathrm{ppm}, 1 \mathrm{ppm}$ dan $2 \mathrm{ppm}$ dengan tiga ulangan. Hasil penelitian menunjukkan bahwa kombinasi perlakuan tanpa 2,4-D dan 0,5 ppm kinetin memberikan respon terbaik pada saat muncul kalus 11,67 HST dan perlakuan 1 ppm 2,4-D dan 2 ppm kinetin memberikan respon terbaik pada persentase keberhasilan induksi kalus $62,50 \%$.
\end{abstract}

Kata kunci: Auksin, Binahong merah, In vitro, Kultur kalus, Sitokinin

\begin{abstract}
Red binahong (Basella rubra L.) is a plant that contains medicinal secondary metabolites. Callus culture is one solution in producing secondary metabolites in large quantities. This research aimed to determine the effect of 2,4-D and kinetin in inducing callus on red binahong leaves. The research was conducted at the Laboratory of Plant Biotechnology, Faculty of Agriculture, the University of Riau from November 2019 to March 2020. The experiment used a randomized block design with two factors, namely four levels of 2,4-D 0, 0.5, 1, and $2 \mathrm{ppm}$ and four levels of kinetin namely $0,0.5,1$, and $2 \mathrm{ppm}$ with three replications. The results showed that a combination of $0 \mathrm{ppm} \mathrm{2,4-D} \mathrm{and} 0.5 \mathrm{ppm}$ kinetin and $1 \mathrm{ppm} \mathrm{2,4-D} \mathrm{and} 2 \mathrm{ppm}$ had the fastest callus formation 11.67 DAP and a combination of $1 \mathrm{ppm} \mathrm{2,4-D} \mathrm{and} 2 \mathrm{ppm}$ kinetin produced weigher callus $6.4 \mathrm{mg}$ and had a percentage of callus formation $62.50 \%$.
\end{abstract}

Key words: Auxin, Callus culture, Cytokinine, In vitro, Red binahong

Cite this as: Silvina, F., Isnaini, Ningsih, W. (2021). Induksi kalus daun binahong merah (Basella rubra L.) dengan pemberian 2,4-D dan kinetin. Jurnal Agro, 8(2), 274-285. https://doi.org/10.15575/14273 


\section{PENDAHULUAN}

Indonesia memiliki keanekaragaman tanaman yang tinggi, termasuk tanaman obat. Salah satu tanaman yang dapat dijadikan obat adalah tanaman binahong merah (Basella rubra L.) yang telah digunakan sebagai bahan baku untuk industri fitofarmaka karena mengandung senyawa metabolit sekunder yang bersifat sebagai anti bakteri, seperti asam askorbat, flavonoid, saponin, terpenoid, steroid, alkaloid dan glikosida (Mulyaningsih, 2014; Astuti et al., 2011; Garmana et al., 2014). Tanaman ini dapat dijadikan sebagai obat anti radang usus, campak, cacar air, gagal ginjal, hipertensi dan inflamasi (Martono et al., 2018; Zhang et al., 2017).

Masalah yang ditemukan dalam pengembangan tanaman obat adalah rendahnya kadar senyawa metabolit sekunder, sehingga dalam pengolahan berskala besar dibutuhkan tanaman dalam jumlah banyak (Manalu et al., 2012). Untuk mengatasi masalah tersebut diperlukan teknik perbanyakan secara in vitro (kultur jaringan) untuk menghasilkan kalus yang memiliki kandungan metabolit sekunder lebih tinggi (Sugiyarto \& Kuswandi, 2014). Senyawa metabolit sekunder yang dihasilkan dari kultur kalus umumnya mampu menghasilkan lebih banyak jenisnya, karena seringkali dihasilkan zat-zat alkaloid atau senyawa-senyawa lain yang berguna untuk pengobatan (Astuti et al., 2011). Tekstur kalus yang kompak memiliki kemampuan menghasilkan metabolit sekunder yang baik (Indah \& Dini, 2013). Sedangkan tekstur kalus yang remah dianggap baik untuk upaya perbanyakan jumlah kalus (Andaryani, 2010).

Salah satu cara yang dapat dilakukan untuk meningkatkan pertumbuhan kalus adalah dengan menambahkan zat pengatur tumbuh ke dalam media. Ada dua jenis zat pengatur tumbuh yang digunakan dalam kultur in vitro, yaitu sitokinin dan auksin. Penggunaan auksin bersama dengan sitokinin memungkinkan kita untuk menentukan jenis morfogenesis yang diinginkan. 2,4-D yang merupakan golongan auksin dan kinetin yang merupakan golongan sitokinin merupakan zat pengatur tumbuh sintetik yang umumnya digunakan dalam penelitian kultur jaringan (Handayani et al., 2019).

Pemberian sitokinin pada kultur kalus berperan penting dalam memicu pembelahan dan pemanjangan sel sehingga dapat mempercepat perkembangan dan pertumbuhan kalus. Pemberian kinetin yang dikombinasikan dengan auksin dapat merangsang terjadinya pembentukan kalus pada eksplan (Hendaryono \& Wijayani, 1994).

Hasil penelitian Sugiyarto \& Kuswandi (2014) mengenai pertumbuhan kalus pada daun binahong hijau menunjukkan bahwa pemberian 1 ppm 2,4-D mampu menghasilkan pembentukan kalus tercepat. Menurut Suparjo et al. (2016) pemberian kinetin pada pertumbuhan kalus daun binahong hijau menghasilkan kalus terbesar pada konsentrasi 0,5 ppm. Khaniyah et al. (2012) menyatakan bahwa penambahan 0,5 ppm 2,4-D dengan 1 ppm kinetin menghasilkan persentase berkalus tertinggi pada daun dewa (Gynura procumbens L.). Hasil penelitian serupa oleh Satria et al. (2019) pemberian konsentrasi 2 ppm 2,4-D dengan $1 \mathrm{ppm}$ kinetin menghasilkan berat kalus terbesar pada eksplan daun kayu manis. Pemberian 2,4-D dan kinetin dapat memacu pertumbuhan kalus pada gandum (Baday, 2018). 
Penelitian ini bertujuan untuk mengetahui pengaruh dari zat pengatur tumbuh 2,4-D dan kinetin serta kombinasi terbaik dalam menginduksi kalus daun binahong merah secara in vitro.

\section{BAHAN DAN METODE}

Penelitian ini dilaksanakan di Laboratorium Bioteknologi Tanaman Fakultas Pertanian Universitas Riau pada bulan November 2019 sampai Maret 2020. Bahan yang digunakan dalam penelitian ini adalah daun muda binahong merah (Basella rubra L.), media MS, gula, agar, 2,4-D, kinetin, $\mathrm{KOH} 1 \mathrm{~N}, \mathrm{HCl} 1 \mathrm{~N}$, deterjen, aquades, alkohol $70 \%$ dan 96\%, clorox, spiritus dan Dithane M 45.

Alat yang digunakan pada penelitian ini adalah laminar air flow Cabinet (LAFC), autoklaf, timbangan analitik, magnetic stirrer, $\mathrm{pH}$ meter, botol kultur, aluminium foil, pinset, scalpel, petridish, gelas ukur, gelas beker, pipet tetes, erlenmeyer, bunsen, munsell plant color chart, lemari es, kompor gas, panci, sendok, korek api, spatula, gunting, hand sprayer, plastik wrap, kertas label, rak kultur, tisu, alat tulis dan kamera.

Pembuatan media tanam dilakukan dengan menimbang media MS instan sebanyak 2,2 g, kemudian ditambahkan gula sebanyak $15 \mathrm{~g}$, lalu ditambahkan stok hormon 2,4-D dan kinetin sesuai konsentrasi perlakuan. Setelah itu volume larutan ditambahkan menjadi $500 \mathrm{ml}$. Selanjutnya dilakukan pengukuran $\mathrm{pH}$ larutan media 5.8. Kemudian ditambahkan agar 4g lalu dipanaskan dan diaduk sampai larutan jernih kemudian diangkat. Media diisikan ke dalam botol kultur masing-masing sebanyak $\pm 20 \mathrm{ml}$ kemudian disterilkan menggunakan autoklaf pada suhu $121^{\circ} \mathrm{C}$ dengan tekanan 17,5 psi selama 10 menit.

Eksplan yang digunakan adalah daun muda ke-2 dari pucuk tanaman binahong merah. Sterilisasi awal dengan merendam eksplan ke dalam larutan deterjen selama 1 menit, selanjutnya dengan larutan Dithane M 45 konsentrasi 0,1\% selama 30 menit dan kemudian dibilas sebanyak tiga kali menggunakan aquades. Sterilisasi kimia dilakukan di dalam Laminar Air Flow Cabinet (LAFC) menggunakan clorox konsentrasi $2 \%$ dan $1 \%$ secara berturut-turut.

Eksplan yang sudah disterilisasi kemudian dipotong dengan ukuran $1 \times 1$ $\mathrm{cm}^{2}$, lalu ditanam di dalam botol kultur sebanyak 2 eksplan per botol dengan bagian bawah daun menyentuh media padat. Botol ditutup dengan aluminium foil, dan dibalut dengan plastik wrap dan diberi label sesuai tanggal penanaman. Botol yang sudah berisi eksplan diinkubasi selama 12 minggu pada ruangan dengan pencahayaan 600-1000 lux.

Penelitian menggunakan rancangan acak kelompok (RAK) yang terdiri dari dua faktor yaitu 2,4-D dengan empat taraf 0 ppm; 0,5 ppm; 1 ppm; 2 ppm dan kinetin dengan empat taraf 0 ppm; 0,5 ppm; 1 ppm; 2 ppm, kombinasi dari masing-masing faktor diulang tiga kali sehingga diperoleh 48 unit percobaan. Pada masing-masing satuan percobaan terdapat 8 botol dimana masingmasing terdiri dari 2 eksplan.

Pengamatan kualitatif dilakukan terhadap warna kalus menggunakan munsell plant color chart dan tekstur kalus sedangkan pengamatan kuantitatif dilakukan terhadap waktu saat muncul kalus dengan menghitung hari muncul kalus sejak eksplan ditanam, berat kalus dengan menimbang kalus menggunakan timbangan analitik, persentase keberhasilan dan persentase kontaminasi. Data yang 
diperoleh dianalisis dengan Sidik Ragam dan dilanjutkan dengan Uji Jarak Berganda Duncan taraf $5 \%$.

$\%$ Keberhasilan $=\frac{\Sigma \text { kalus terbentuk }}{\Sigma \text { eksplan total }} \times 100 \%$

$\%$ Kontaminasi $=\frac{\Sigma \text { terkontaminasi }}{\Sigma \text { eksplan } \text { total }} \times 100 \%$

\section{HASIL DAN PEMBAHASAN}

\section{Warna Kalus dan Tekstur Kalus}

Morfologi kalus meliputi warna dan tekstur kalus. Warna dan tekstur kalus digunakan sebagai indikator kualitas kalus (Gambar 1 dan Gambar 2).

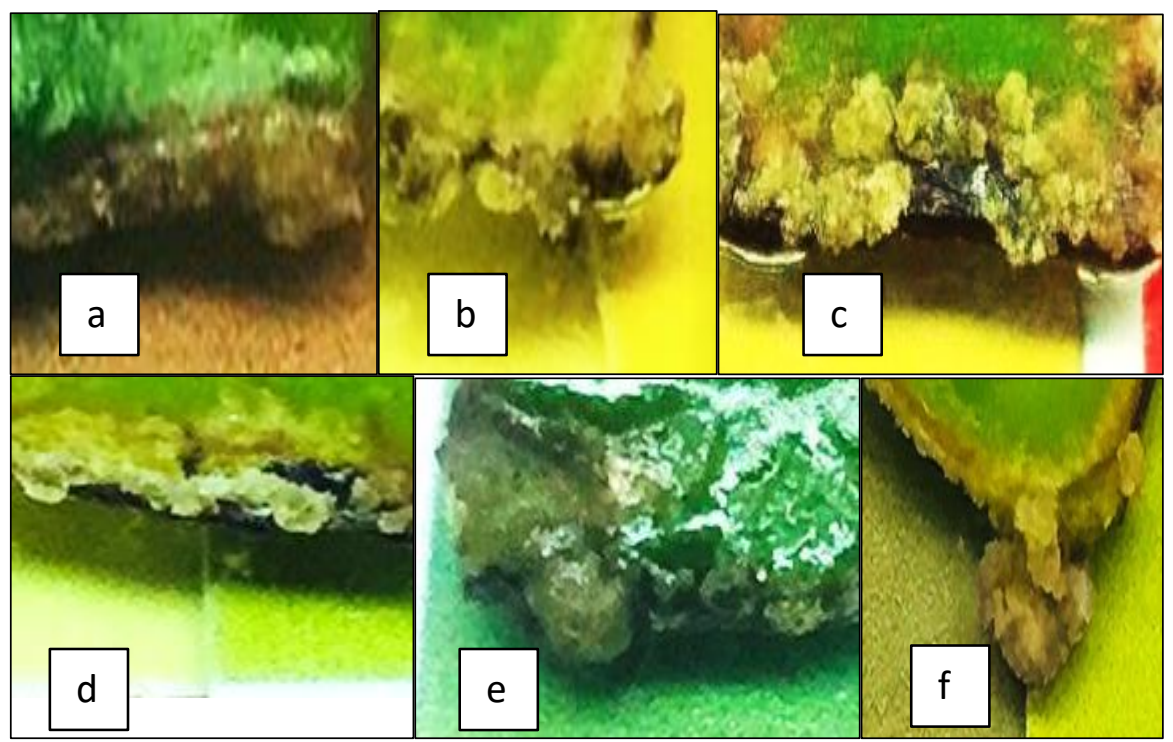

Gambar 1. Penampakan warna kalus binahong merah yang diinduksi pada media MS dengan penambahan 2,4-D dan kinetin pada umur 12 MST. a) kalus warna coklat (0 ppm 2,4-D dan 0 ppm kinetin), b) kalus warna kuning (2 ppm 2,4-D dan 0 ppm kinetin), c) kalus warna kuning keputihan (1 ppm 2,4-D dan 2 ppm kinetin), d) kalus warna hijau keputihan (0,5 ppm 2,4-D dan kinetin 1 ppm), e) kalus warna hijau (0 ppm 2,4-D dan kinetin 2 ppm), f) kalus warna hijau kekuningan (0,5 ppm 2,4-D dan 2 ppm kinetin)

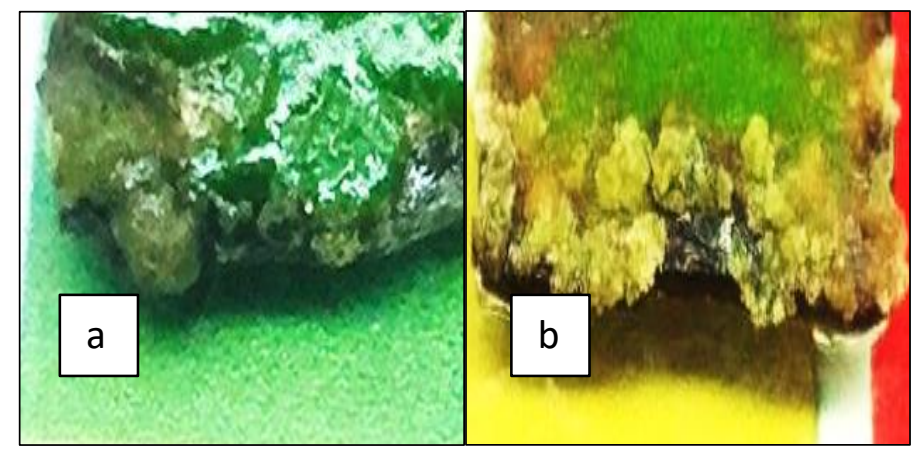

Gambar 2. Penampakan tekstur kalus binahong merah yang diinduksi dengan media MS dengan penambahan 2,4-D dan kinetin pada umur $12 \mathrm{MST}$. a) kalus berstruktur kompak (0 ppm 2,4-D dan 2 ppm kinetin), b) kalus berstruktur remah (1 ppm 2,4-D dan 2 ppm kinetin)

Tabel 1 menunjukkan bahwa kalus yang muncul pada eksplan daun binahong merah memiliki warna yang beragam. Kombinasi pemberian 0 ppm 2,4-D dan 0 ppm kinetin 
serta 0 ppm 2,4-D dan 0,5 ppm kinetin menghasilkan kalus dominan berwarna coklat. Kalus yang berwarna coklat (semakin gelap) menunjukkan pertumbuhan kalus semakin menurun (Widyawati dan Geningsih, 2010).

Tabel 1. Hasil pengamatan terhadap warna dan tekstur kalus binahong merah pada pemberian 2,4-D dan kinetin

\begin{tabular}{|c|c|c|}
\hline Perlakuan & Warna Kalus & Tekstur Kalus \\
\hline 0 ppm 2,4-D + 0 ppm kinetin & Coklat (1Y 7/4) & Kompak \\
\hline \multirow[t]{3}{*}{$0,5 \mathrm{ppm}$ 2,4-D + 0 ppm kinetin } & Dominan kuning $(7,5 Y 8,5 / 12)$ & Dominan kompak \\
\hline & Hijau (5GY 8/9) & Remah \\
\hline & Hijau kekuningan $(2,5 \mathrm{GY9} / 6)$ & \\
\hline \multirow[t]{3}{*}{$1 \mathrm{ppm}$ 2,4-D + 0 ppm kinetin } & Dominan kuning keputihan $(7,5 \mathrm{Y} 9 / 2)$ & Dominan remah \\
\hline & Hijau keputihan (5GY9/2) & Kompak \\
\hline & Coklat $(10 Y 5 / 4,5)$ & \\
\hline \multirow[t]{3}{*}{2 ppm 2,4-D + 0 ppm kinetin } & Dominan kuning $(5 Y 9 / 6)$ & Dominan remah \\
\hline & Hijau kekuningan (5 GY 8/9) & Kompak \\
\hline & Coklat (5Y 7/4) & \\
\hline \multirow[t]{2}{*}{0 ppm 2,4-D + 0,5 ppm kinetin } & Dominan coklat $(1 Y 5,7 / 4)$ & Dominan kompak \\
\hline & Hijau kekuningan $(2,5 \mathrm{GY} 9 / 6)$ & Remah \\
\hline \multirow[t]{2}{*}{0,5 ppm 2,4-D + 0,5 ppm kinetin } & Dominan kuning $(7,5 Y 9 / 6)$ & Dominan remah \\
\hline & Hijau kekuningan (2,5 GY 8/9) & Kompak \\
\hline $1 \mathrm{ppm}$ 2,4-D + 0,5 ppm kinetin & - & - \\
\hline 2 ppm 2,4-D + 0,5 ppm kinetin & - & - \\
\hline \multirow[t]{2}{*}{0 ppm 2,4-D + 1 ppm kinetin } & Dominan hijau $(2,5 G$ 7/10) & Dominan kompak \\
\hline & Coklat $(7,5 Y 5 / 4,5)$ & Remah \\
\hline \multirow[t]{3}{*}{$0,5 \mathrm{ppm} 2,4-\mathrm{D}+1 \mathrm{ppm}$ kinetin } & Dominan kuning $(7,5 Y 8,5 / 12)$ & Dominan remah \\
\hline & Hijau kekuningan $(2,5 \mathrm{GY} 9 / 6)$ & Kompak \\
\hline & Hijau keputihan (7,5 GY 8/2) & \\
\hline \multirow[t]{2}{*}{$1 \mathrm{ppm} 2,4-\mathrm{D}+1 \mathrm{ppm}$ kinetin } & Dominan kuning $(7,5 Y 8,5 / 12)$ & Dominan remah \\
\hline & Hijau kekuningan(2,5 GY 8/9) & Kompak \\
\hline 2 ppm 2,4-D + 1 ppm kinetin & - & - \\
\hline \multirow[t]{2}{*}{0 ppm 2,4-D + 2 ppm kinetin } & Dominan hijau (2,5G 7/10.5) & Dominan kompak \\
\hline & Coklat $(2,5 \mathrm{GY} 5,7 / 4)$ & Remah \\
\hline \multirow[t]{2}{*}{$0,5 p p m$ 2,4-D + 2 ppm kinetin } & Dominan hijau kekuningan (2,5 GY 8/9) & Dominan remah \\
\hline & Kuning $(7,5$ GY $8,5 / 12)$ & Kompak \\
\hline \multirow{3}{*}{1 ppm 2,4-D + 2 ppm kinetin } & Dominan kuning keputihan $(7,5 \mathrm{GY} 8 / 9)$ & Dominan remah \\
\hline & Kuning (5Y 8,5/12) & Kompak \\
\hline & Hijau $(7,5$ GY $7 / 4)$ & \\
\hline $2 p p m$ 2,4-D + 2 ppm kinetin & - & - \\
\hline
\end{tabular}

Ket: $(-)$ = tidak terbentuk kalus pada eksplan. Angka didalam kurung merupakan nomor color chart yang diikuti dengan nilai kecerahan warna.

Warna kekuningan pada kalus dihasilkan dari kombinasi pemberian 0,5 ppm, $1 \mathrm{ppm}$, dan 2 ppm 2,4-D masing-masing dengan 0 ppm kinetin, pemberian 0,5 ppm 2,4-D dengan masing-masing 0,5 ppm dan $1 \mathrm{ppm}$ kinetin, serta pemberian 1 ppm 2,4-D dengan masing-masing $1 \mathrm{ppm}$ dan $2 \mathrm{ppm}$ kinetin. Warna kehijauan pada kalus dihasilkan pada kombinasi pemberian 0 ppm 2,4-D dengan masing-masing $1 \mathrm{ppm}$ dan 2 ppm kinetin serta 0,5 ppm 2,4-D dan 2 ppm kinetin. Kalus yang berwarna hijau menandakan adanya kandungan klorofil 
pada kalus. Kalus yang berwarna putih hingga kekuningan merupakan kalus yang berkembang dengan baik dan aktif mengalami pembelahan sel serta mengandung kloroplas yang tinggi (Ariati et al., 2012).

Tekstur kalus yang muncul pada eksplan daun binahong merah bersifat kompak dan remah (Tabel 1). Kalus remah dominan dihasilkan dari pemberian 0,5 ppm, 1 ppm dan 2 ppm 2,4-D yang dikombinasikan dengan berbagai konsentrasi kinetin. Hal ini sesuai dengan penelitian Khalida (2019) yang menyatakan bahwa pemberian konsentrasi 2,4-D yang semakin tinggi menghasilkan kalus yang bertekstur remah. Tekstur kalus yang remah mengalami pembelahan sel yang cepat daripada kalus dengan tekstur kompak, hal ini karena kalus kompak membentuk lignifikasi sehingga kalus bertekstur keras (Mahadi, 2016).

Kalus dengan tekstur remah baik untuk kultur suspensi karena memiliki sel tunggal yang mudah dipisahkan. Dengan demikian, kalus yang bertekstur remah memudahkan upaya perbanyakan jumlah massa kalus melalui kultur suspensi. Yelnitis (2012) menyatakan kalus remah baik untuk kultur suspensi dalam upaya perbanyakan massa sel. Khaniyah et al. (2012) menyatakan bahwa pemberian 2,4-D dan kinetin pada tanaman daun dewa menghasilkan kalus bertekstur remah dan kompak.

Pemberian kombinasi 0 ppm 2,4-D dengan masing-masing $0 \mathrm{ppm}, 0,5 \mathrm{ppm}, 1$ ppm dan $2 \mathrm{ppm}$ serta pemberian $0,5 \mathrm{ppm}$ 2,4-D dan 0 ppm kinetin membentuk kalus bertekstur kompak. Kalus kompak cenderung mengalami pembelahan sel yang lebih lambat jika dibandingkan dengan kalus remah. Kalus bertekstur kompak disebabkan adanya perbedaan kemampuan jaringan tanaman dalam menyerap unsur hara dan zat pengatur tumbuh dalam media inisiasi (Ariati et al., 2012).

\section{Saat Muncul Kalus}

Hasil analisis ragam menunjukkan bahwa pemberian 2,4-D dan kinetin berpengaruh nyata terhadap saat muncul kalus. Munculnya kalus diawali dengan pembengkakan eksplan pada bagian perlukaan disertai dengan munculnya bercak putih. Menurut Yelnitis (2012) induksi kalus diawali dengan penebalan eksplan pada bagian potongan dan di daerah yang mengalami pelukaan. Penebalan tersebut merupakan hasil interaksi antara eksplan dengan media tumbuh, zat pengatur tumbuh dan lingkungan tumbuh sehingga eksplan bertambah besar.

Tabel 2 menunjukkan bahwa pada perlakuan pemberian 2,4-D dan kinetin memperlihatkan muncul kalus tercepat pada pemberian 0,5 ppm kinetin tanpa 2,4$D$ dibandingkan dengan perlakuan lainnya serta tidak berbeda nyata dengan pemberian 1 ppm 2,4-D dan 2 ppm kinetin. Pada penelitian sebelumnya yang dilakukan oleh Triana (2015) pada daun binahong menghasilkan waktu muncul kalus tercepat pada konsentrasi media 2,4-D 0,5 ppm, 1 ppm dan 1,5 ppm. Marlin et al. (2012) menyatakan bahwa untuk pembentukan kalus diperlukan auksin dalam jumlah yang relatif tinggi sehingga dapat memacu pembentukan kalus dan menekan morfogenesis. Namun pada penelitian ini pemberian 2,4-D yang tinggi tidak terjadi.

Perbedaan laju pertumbuhan kalus selain dipengaruhi oleh peningkatan kecepatan pembelahan sel karena pengaruh pemberian hormon juga dipengaruhi oleh kondisi genetik, umur jaringan, dan jenis tanaman serta faktor 
lingkungan yang meliputi cahaya, kandungan $\mathrm{O}_{2}$, suhu, dan kelembaban udara serta kemampuan jaringan menyerap zatzat hara yang tersedia (Mahadi et al,. 2016). Menurut Sitinjak et al. (2015) pemberian auksin sering menjadi lebih efektif saat dikombinasikan dengan sitokinin, termasuk dalam memacu pembentukan dan pertumbuhan sel-sel pada pembentukan kalus. Dwipayana et al. (2016), menyatakan bahwa pembengkakan pada eksplan terjadi karena adanya pengaruh pemberian 2,4-D yang memacu pembelahan dan perbanyakan sel yang selanjutnya akan membentuk kalus. Pembesaran sel meningkatkan plastisitas dinding sel dan pembentukan enzim selulase yang dapat melarutkan selulosa dinding sel, menyebabkan oksigen, air dan mineral lewat untuk pertumbuhan dan pembesaran sel (Budi Santoso et al., 2017). Hasil penelitian Suparjo et al. (2016) menyatakan bahwa pemberian 2,4-D mampu membentuk kalus lebih cepat dan dengan ukuran yang lebih besar.

Tabel 2. Rata-rata saat muncul kalus (hari) binahong merah pada pemberian 2,4-D dan kinetin

\begin{tabular}{ccccc}
\hline \multirow{2}{*}{ Dosis 2,4-D (ppm) } & \multicolumn{4}{c}{ Kinetin $(\mathrm{ppm})$} \\
\cline { 2 - 5 } & 0 & 0,5 & 1 & 2 \\
\hline 0 & $57,17 \mathrm{a}$ & $11,67 \mathrm{ab}$ & $26,00 \mathrm{a}$ & $27,50 \mathrm{~b}$ \\
& $\mathrm{~A}$ & $\mathrm{~A}$ & $\mathrm{~A}$ & $\mathrm{~A}$ \\
0,5 & $28,10 \mathrm{a}$ & $34,00 \mathrm{a}$ & $26,66 \mathrm{a}$ & $30,75 \mathrm{a}$ \\
& $\mathrm{AB}$ & $\mathrm{A}$ & $\mathrm{B}$ & $\mathrm{AB}$ \\
1 & $46,15 \mathrm{a}$ & $0,00 \mathrm{~b}$ & $34,33 \mathrm{a}$ & $15,17 \mathrm{~b}$ \\
& $\mathrm{~A}$ & $\mathrm{~B}$ & $\mathrm{AB}$ & $\mathrm{B}$ \\
2 & $45,58 \mathrm{a}$ & $0,00 \mathrm{~b}$ & $0,00 \mathrm{~b}$ & $0,00 \mathrm{~b}$ \\
& $\mathrm{~A}$ & $\mathrm{~B}$ & $\mathrm{~B}$ & $\mathrm{~B}$ \\
\hline
\end{tabular}

Angka yang diikuti huruf Kapital yang sama arah horizontal (baris) dan angka yang diikuti huruf kecil yang sama arah vertikal (kolom) tidak berbeda nyata berdasarkan hasil Uji Duncan pada taraf $5 \%$. Data ditransformasi menggunakan $\sqrt{y}+0,5$

Ket: Angka nol $(0,00)$ menandakan tidak terbentuknya kalus pada eksplan

\section{Berat Kalus}

Hasil analisis ragam terhadap berat kalus menunjukkan adanya pengaruh nyata pemberian 2,4-D dan kinetin (Tabel 3). Berat kalus yang dihasilkan sangat tergantung pada kecepatan sel-sel tersebut membelah diri, memperbanyak diri dan dilanjutkan dengan membesarnya kalus.

Tabel 3 menunjukkan bahwa kombinasi pemberian 2,4-D dan kinetin tidak nyata meningkatkan berat kalus binahong merah, namun terlihat kecenderungan peningkatan yang sangat tinggi untuk berat kalus pada pemberian kombinasi 1 ppm 2,4-D dan 2 ppm kinetin dibandingkan dengan pemberian tanpa 2,4-D dan 0,5 ppm kinetin. Hal ini diduga bahwa pemberian tanpa 2,4-D dan 0,5 ppm kinetin belum mampu untuk meningkatkan berat kalus karena tidak tersedianya auksin sintetik pada media. Auksin sintetik perlu ditambahkan karena auksin yang terbentuk secara alami pada tanaman sering tidak mencukupi untuk pertumbuhan jaringan eksplan. Menurut Satria et al. (2019) pemberian konsentrasi 2 ppm 2,4-D dengan 1 ppm kinetin menghasilkan berat kalus terbesar pada eksplan daun kayu manis. Pembelahan sel yang optimal akan menyebabkan pertumbuhan kalus yang 
optimal sehingga menambah berat segar kalus terutama pada perlakuan yang diberikan. Menurut Robles et al. (2016) menyatakan bahwa penggunaan auksin jenis 2,4-D dapat mempercepat pertumbuhan kalus, menaikkan tekanan osmotik meningkatkan permeabilitas sel terhadap air, pengurangan tekanan pada dinding sel, meningkatkan sintesis protein, meningkatkan plastisitas, dan pengembangan dinding sel.

Tabel 3. Rata-rata berat kalus (mg) binahong merah pada pemberian 2,4-D dan kinetin

\begin{tabular}{ccccc}
\hline \multirow{2}{*}{ Konsentrasi 2,4-D (ppm) } & \multicolumn{5}{c}{ Kinetin (ppm) } \\
\cline { 2 - 5 } & 0 & 0,5 & 1 & 2 \\
\hline 0 & $1,60 \mathrm{~b}$ & $0,60 \mathrm{~b}$ & $4,00 \mathrm{ab}$ & $3,50 \mathrm{ab}$ \\
& $\mathrm{B}$ & $\mathrm{B}$ & $\mathrm{A}$ & $\mathrm{A}$ \\
0,5 & $3,50 \mathrm{a}$ & $4,10 \mathrm{a}$ & $4,60 \mathrm{a}$ & $5,00 \mathrm{ab}$ \\
& $\mathrm{A}$ & $\mathrm{A}$ & $\mathrm{A}$ & $\mathrm{A}$ \\
1 & $4,30 \mathrm{a}$ & $0,00 \mathrm{~b}$ & $2,30 \mathrm{~b}$ & $6,40 \mathrm{a}$ \\
& $\mathrm{A}$ & $\mathrm{B}$ & $\mathrm{AB}$ & $\mathrm{A}$ \\
2 & $3,40 \mathrm{ab}$ & $0,00 \mathrm{~b}$ & $0,00 \mathrm{~b}$ & $0,00 \mathrm{~b}$ \\
& $\mathrm{~A}$ & $\mathrm{~B}$ & $\mathrm{~B}$ & $\mathrm{~B}$ \\
\hline
\end{tabular}

Angka yang diikuti huruf kapital yang sama arah horizontal (baris) dan angka yang diikuti huruf kecil yang sama arah vertikal (kolom) tidak berbeda nyata berdasarkan hasil Uji Duncan pada taraf $5 \%$. Data ditransformasi menggunakan $\sqrt{y}+0,5$

Ket: Angka nol $(0,00)$ menandakan tidak terbentuknya kalus pada eksplan

\section{Persentase Keberhasilan}

Hasil analisis ragam menunjukkan adanya pengaruh nyata pemberian 2,4-D dan kinetin pada persentase keberhasilan induksi kalus binahong merah (Tabel 4). Kalus dapat terbentuk sesuai dengan teori totipotensi yang menyatakan bahwa setiap sel mempunyai kemampuan untuk tumbuh menjadi individu baru jika berada pada lingkungan yang sesuai.

Tabel 4 menunjukkan bahwa persentase keberhasilan induksi kalus tertinggi ditunjukkan pada pemberian $1 \mathrm{ppm}$ 2,4-D dan 2 ppm kinetin dibandingkan dengan 1 ppm 2,4-D dan 0,5 ppm kinetin serta 2 ppm 2,4-D dengan masing-masing 0,5 ppm, $1 \mathrm{ppm}, 2 \mathrm{ppm}$ kinetin, namun tidak berbeda nyata dengan pemberian $0,5 \mathrm{ppm}$ 2,4-D dengan masing-masing tanpa, 0,5 ppm, 1 ppm, 2 ppm kinetin serta pemberian 2 ppm 2,4-D dan tanpa kinetin.

Hal ini diduga bahwa konsentrasi 2,4-D dan kinetin yang diberikan mampu menginduksi kalus dengan baik. Ketidakmampuan eksplan dalam membentuk kalus disebabkan oleh kurang tepatnya penggunaan zat pengatur tumbuh yang digunakan. Konsentrasi yang terlalu tinggi dapat menghambat perkembangan bagi eksplan sehingga menyebabkan kalus tidak terbentuk, sedangkan konsentrasi yang terlalu rendah seringkali tidak mampu memicu pembentukan kalus (Khaniyah et al., 2012). 
Tabel 4. Rata-rata persentase keberhasilan induksi kalus binahong merah pada pemberian 2,4D dan kinetin

\begin{tabular}{ccccc}
\hline \multirow{2}{*}{ Dosis 2,4-D (ppm) } & \multicolumn{4}{c}{ Kinetin (ppm) } \\
\cline { 2 - 5 } & 0 & 0,5 & 1 & 2 \\
\hline 0 & $12,50 \mathrm{~b}$ & $16,67 \mathrm{~b}$ & $25,00 \mathrm{~b}$ & $25,00 \mathrm{ab}$ \\
& $\mathrm{A}$ & $\mathrm{A}$ & $\mathrm{A}$ & $\mathrm{A}$ \\
0,5 & $50,00 \mathrm{a}$ & $50,00 \mathrm{a}$ & $50,00 \mathrm{a}$ & $50,00 \mathrm{a}$ \\
& $\mathrm{A}$ & $\mathrm{A}$ & $\mathrm{A}$ & $\mathrm{A}$ \\
1 & $37,50 \mathrm{ab}$ & $0,00 \mathrm{~b}$ & $25,00 \mathrm{~b}$ & $62,50 \mathrm{a}$ \\
& $\mathrm{AB}$ & $\mathrm{B}$ & $\mathrm{AB}$ & $\mathrm{A}$ \\
2 & $50,00 \mathrm{a}$ & $0,00 \mathrm{~b}$ & $0,00 \mathrm{c}$ & $0,00 \mathrm{~b}$ \\
& $\mathrm{~A}$ & $\mathrm{~B}$ & $\mathrm{~B}$ & $\mathrm{~B}$ \\
\hline
\end{tabular}

Angka yang diikuti huruf kapital yang sama arah horizontal (baris) dan angka yang diikuti huruf kecil yang sama arah vertikal (kolom) tidak berbeda nyata berdasarkan hasil Uji Duncan pada taraf 5\%. Data ditransformasi menggunakan $\sqrt{y}+0,5$

Ket: Angka nol $(0,00)$ menandakan tidak terbentuknya kalus pada eksplan

\section{Persentase Kontaminasi}

Gambar 3 menunjukkan bahwa kontaminasi yang terjadi pada penelitian ini berkisar antara $16,67 \%$ sampai $54,17 \%$. Kontaminasi eksplan binahong merah seluruhnya disebabkan oleh jamur. Eksplan yang terkontaminasi jamur atau mikroorganisme lain akan sulit tumbuh karena nutrisi pada media akan digunakan oleh mikroorganisme, sehingga eksplan yang terkontaminasi sulit tumbuh dan akhirnya mati. Menurut Oratmangun (2017) Kontaminasi dapat terjadi karena adanya mikroorganisme yang masuk kedalam media, botol kultur atau alat-alat yang kurang steril, ruang kerja dan kultur yang kotor, kecerobohan saat penanaman serta dapat berasal dari eksplan baik internal maupun eksternal (Oratmangun, 2017; Ray dan Ali, 2016; Fang dan Hsu, 2012). Faktor internal berupa kontaminan dari dalam jaringan tanaman dan faktor eksternal berupa kontaminan yang berada pada permukaan eksplan.
Keberadaan mikroba yang pertumbuhannya mendominasi eksplan menyebabkan terjadinya persaingan nutrisi di dalam media, membatasi ketersediaan oksigen, serta meningkatkan kematian tanaman kultur (Orlikowska et al., 2017; Nadha et al., 2012). Lamanya respon kontaminasi internal ini terjadi karena mikroorganisme yang terdapat dalam ruang antar sel memerlukan waktu untuk keluar. Setelah keluar, mikroorganisme akan menginfeksi seluruh bagian eksplan.

Munculnya kontaminasi jamur pada penelitian ini diduga akibat faktor internal. Kontaminasi yang disebabkan oleh jamur ini mulai terlihat pada 11 HST yang diawali dengan adanya bintik putih disekitar eksplan dan terus-menerus menyebar menutupi permukaan. Penyebab kontaminasi internal terjadi karena bahan aktif serta durasi waktu dalam sterilisasi belum mampu menghilangkan sumber kontaminasi yang berada di dalam jaringan. 


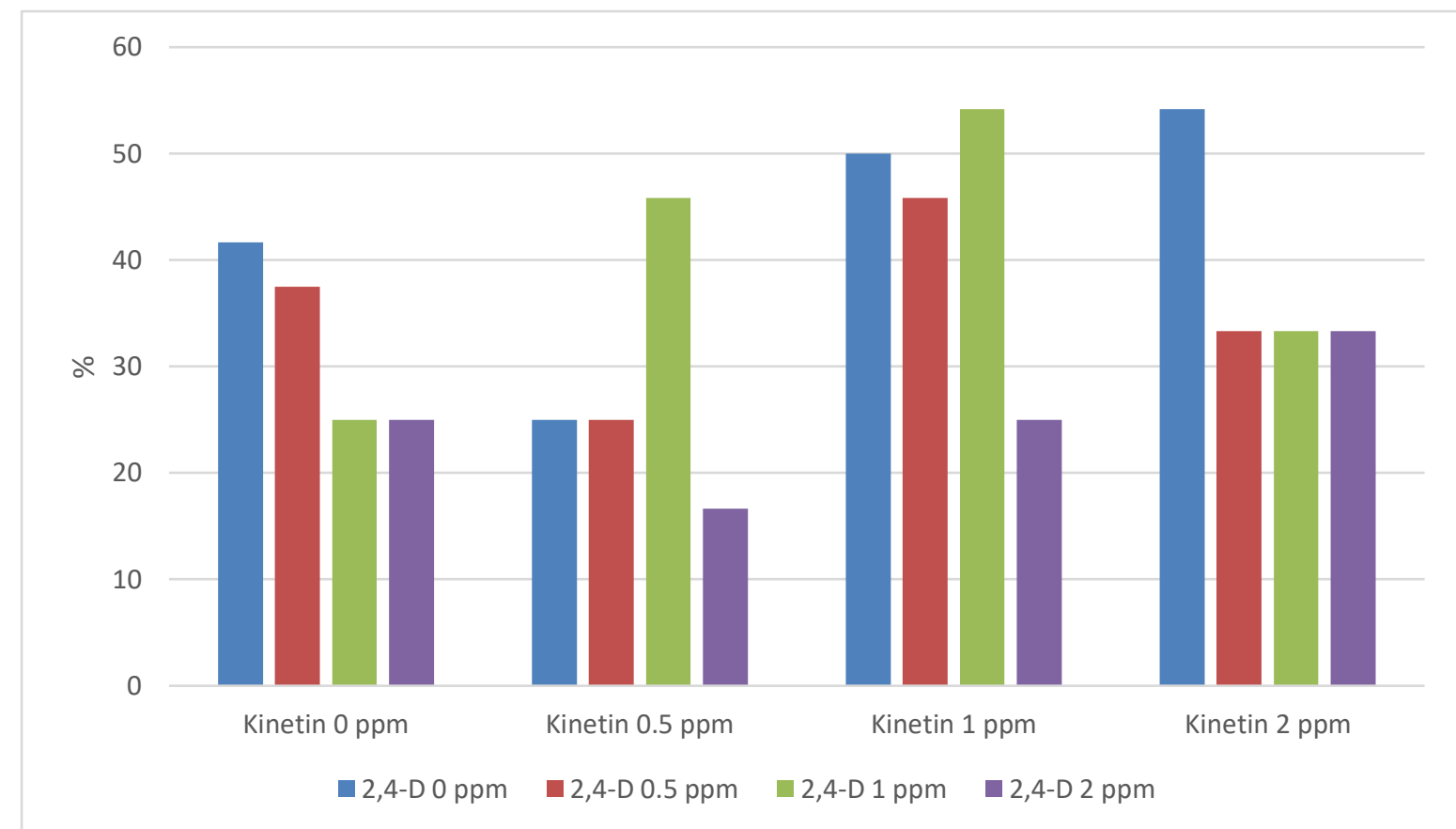

Gambar 3. Grafik rata-rata persentase kontaminasi induksi kalus binahong merah pada pemberian 2,4D dan kinetin

\section{SIMPULAN}

Berdasarkan hasil penelitian yang telah dilaksanakan dapat diambil kesimpulan bahwa Kombinasi pemberian tanpa 2,4-D dan 0,5 ppm kinetin memberikan respon terbaik pada saat muncul kalus yaitu 11.67 HST dan perlakuan 1 ppm 2,4-D dan 2 ppm kinetin memberikan respon terbaik pada persentase keberhasilan induksi kalus yaitu $62.50 \%$.

\section{DAFTAR PUSTAKA}

Andaryani, S. (2010). Kajian penggunaan berbagai konsentrasi BAP dan 2,4-D terhadap induksi kalus jarak pagar (Jatropha curcas L.) secara in vitro. Skripsi. Fakultas Pertanian. Surakarta: Universitas Sebelas Maret.

Ariati, S. N., Waeniati., Muslimin dan I. N. Suwastika. (2012). Induksi kalus tanaman kakao (Theobroma cacao L.) pada media MS dengan penambahan 2,4-D, BAP dan air kelapa. Jurnal Natural Science. 1(1):74-84.

Astuti, S.M., S. A. M. Mimi., A. B. M. Retno dan
A. Risch. (2011). Determination of Saponin from Anredera Cordifolia (Ten) Steenis Plant (Binahong) to Potential Treatment for Several Diseases. J. Agr Sci.3(2):224-232.

https://doi.org/10.5539/jas.v3n4p224

Baday, S. J. S. (2018). In vitro study of the callus induction of two varieties of wheat seeds by plant growth regulators. Biochem Cell Arch. 18(2):2067-2071. http://dx.doi.org/10.36478/aj.2018.67. 71

Budisantoso, I., N. Amalia., dan Kamsinah. (2017). In vitro callus induction from leaf explants of Vanda SP stimulated by 2,4D. Biosaintifika. 9(3):492-497. https://doi.org/10.15294/biosaintifika.v 9i3.11018

Dwipayana, G. A. J., H. Yuswanti dan I. A. Mayun. (2016). Induksi kalus stroberi (Fragaria sp.) melalui aplikasi asam 2,4 Diklorofenoksiasetat secara in vitro. EJurnal Agroekoteknologi Tropika. 5(3): 310321.

Fang, J. Y., and Y. R. Hsu. (2012). Molecular identification and antibiotic control of 
endophytic bacterial contaminants from micropropagated Aglaonema cultures. Plant Cell, Tissue and Organ Culture, 110(1):53-62.

https://doi.org/10.1007/s11240-0120129-6

Garmana A. N., E. Y. Sukandar dan I. Fidriany. (2014). Activity of Several Plant Extracts Against Drug-Sensitive and DrugResistant Microbes. Procedia Chemistry. 13:164-169. DOI: 10.1016/j.proche.2014.12.021

Handayani, S. Rd., I. Yunus., M. Sayuti dan E. Irawan. (2019). In-vitro callus induction of durian (Durio zibethinus Murr.) leaves using kinetin and 2,4-d (dichlorophenoxyacetic acid). J. Trop. Hort. 2(2):59-64.

Hendaryono, D. P. S dan A. Wijayani. (1994). Teknik kultur jaringan pengenalan dan petunjuk perbanyakan tanaman secara vegetatif-modern. Yogyakarta: Kanisius.

Indah, P.N dan E. Dini. (2013). Induksi kalus daun nyamplang (Calophyllum inophyllum Linn.) pada beberapa kombinasi konsentrasi 6Benzylaminopurine (BAP) dan 2,4Dichlorophenoxyacetic Acid (2,4-D). Jurnal Sains dan Seni Pomits. 2(1): E1-E6. https://dx.doi.org/10.12962/j23373520 .v2i1.2571

Khalida, A., Suwirmen dan Z. A. Noli. (2019). Induksi kalus anggrek lilin (Aerides odorata Lour.) dengan pemberian beberapa konsentrasi 2,4-D. Jurnal Biologi Universitas Andalas. 7(2): 109117.

Khaniyah, S., N. A. Habibah dan Sumadi. (2012). Pertumbuhan kalus daun dewa (Gynura prochumbens) dengan penambahan 2,4-D dan Kinetin secara in vitro. Biosantifika. 2(4): 98-105. DOI: https://doi.org/10.15294/biosainti fika.v4i2.2274

Mahadi, I., W. Syafi'i dan Y. Sari. (2016).
Pengaruh pemberian hormon 2,4-D dan BAP terhadap pertumbuhan kalus jeruk kasturi (Citrus microcarpa). Jurnal Biogenesis. 12(2): 99-104.

Manalu, M. M., K. R. Wirasutisna dan Elfahmi. (2012). Produksi senyawa metabolit sekunder melalui kultur jaringan dan transformasi genetik Artemisia annua L.. Acta Pharmaceutica Indonesia. 37(1): 23-27.

Marlin, Yulian dan Hermansyah. (2012). Inisiasi Kalus Embriogenik pada Kultur Jantung Pisang Curup dengan Penambahan Sukrosa, BAP dan 2,4-D. Jurnal Agrivor. 11(2):275-283.

Martono, Y., A. Setiawan dan S. Widodo. (2018). Sarana budidaya tanaman obat keluarga (SABDA TOGA) untuk daerah perkotaan di RT 04 dan RT 06 RW 07 Kelurahan Tegalrejo Salatiga. Jurnal Pengabdian Masyarakat Indonesia. 1(1):1-10. doi:0.11594/bjpmi.01.01.01

Mulyaningsih, Sri. (2014). Analisis pemanfaatan daun binahong (Anredera cordifolia, Steenis.) sebagai antimikroba. Jurnal Pendidikan Biologi.

Nadha, H. K., R. Salwan, R. C. Kasana, M. Anand, dan A. Sood. (2012). Identification and elimination of bacterial contamination during in vitro propagation of Guadua angustifolia Kunth. Pharmacognosy Magazine. 8(30):93-97. http://dx.doi.org/10.4103/09731296.96547

Oratmangun, K. M., D.Pandiangan dan F. E. Kandou. (2017). Deskripsi jenis-jenis kontaminan dari kultur kalus Catharanthus roseus (L.) G. Don. Jurnal MIPA Unsrat Online. 6(1): 47-52. DOI: https://doi.org/10.35799/jm.6.1.2 017.16154

Orlikowska, T., K. Nowak, dan B. Reed. (2017). Bacteria in the plant tissue culture environment. Plant Cell, Tissue, and 
Organ Culture. 128(3): 487-508. https://link.springer.com/article/10.100 7/s11240-016-1144-9

Ray, S. S. and N. Ali. (2016). Biotic contamination and possible ways of sterilization review with reference to bamboo micropropagation. Brazilian Archives of Biology and Technology. 59: 1-10. http://dx.doi.org/10.1590/16784324-2016160485

Robles-Martinez, M., A. P. Barba-de la Rosa., F. Gueroud., A. Negre-Salvayre., M. Rossignol., dan M. S. Santos-Diaz. (2016). Establishment of callus and cell suspensions of wild and domesticated Opuntia species: Study on their potential as a source of metabolite production. Plant Cell Tissue and Organ Culture. 124(1):181-189.

Satria, M. T., Neliyati dan Jasminarni. (2019). Pengaruh zat pengatuh tumbuh 2,4-D dan kinetin terhadap induksi kalus dari eksplan daun kayu manis Cinnamomum burmanii. Jurnal agroecotenia. 2(1): 3951.

Sitinjak, M. A., M. N. Isda dan S. Fatonah. (2015). Induksi kalus dari eksplan daun in vitro keladi tikus (Typhonium sp.) dengan perlakuan 2,4-D dan kinetin. $A l$ Kauniyah Jurnal Biologi. 8(1): 3239. https://doi.org/10.15408/kauniyah.v8i1 .2703

Sitorus, E. N., E. D. Hastuti dan N. Setiari. (2011). Induksi kalus binahong Basella rubra L. secara in vitro pada media MS dengan konsentrasi sukrosa yang berbeda. Bioma. 13(1). https://doi.org/10.14710/bioma.13.1.17
Sugiyarto, L dan P. C. Kuswandi. (2014). Induksi kalus daun binahong (Anredera cordifolia L.) dalam upaya pengembangan tanaman obat tradisional. J. Sains Dasar. 3(1):56-60.

Suparjo., J. I. Royani., S. Rosmalawati., T. Tajuddin dan A. Riyadi. (2016). Pengaruh auksin dan sitokinin terhadap perbanyakan mikro tanaman binahong (Anredera cordifolia (Tenore) Steenis). Jurnal Bioteknologi dan Biosains Indonesia. 3(2):57-65. https://doi.org/10.29122/jbbi.v3i2.72

Triana, F dan T. Rahayu. (2015). Induksi kalus pada eksplan daun tanaman Binahong (Anredera cordifolia) secara in vitro dengan konsentrasi 2,4-D dan BAP yang berbeda. Jurnal UMS.

Widyawati, Geningsih. (2010). Pengaruh variasi konsentrasi naa dan bap terhadap induksi kalus jarak pagar (Jatropha curcas L. Tesis. Biosains. Surakarta: Universitas Sebelas Maret.

Yelnitis. (2012). Pembentukan kalus remah dari eksplan daun ramin (Gonystylus bancanus (Miq) Kurz.). J. Pemuliaan Tanaman Hutan. 6(3): 1. https://doi.org/10.20886/jpth.2012.6.3. 181-194

Zhang, Z. P., C. C. Shen., F.L. Gao., H. Wei., D.F Ren., dan J. Lu. (2017). Isolation, purification, and structural characterization of two novel watersoluble polysaccharides from Anredera cordifolia. Molecules. (22):1276. https://doi.org/10.3390/molecules2208 1276 